\title{
17. CRETACEOUS TO RECENT SUBMARINE FANS IN THE SOUTHEAST ANGOLA BASIN ${ }^{1}$
}

\author{
Dorrik A. V. Stow, Grant Institute of Geology, University of Edinburgh, Edinburgh, Scotland, \\ EH9 3JW, United Kingdom
}

\begin{abstract}
There have been three periods in the past 100 m.y. during which sedimentation at Site 530 in the S.E. Angola Basin has been dominated by mass gravity processes. These three successions, each between $200 \mathrm{~m}$ and $300 \mathrm{~m}$ thick, can be interpreted as deep-sea fan accumulations on the basis of their morphology, seismic stratigraphy, and facies sequences and have been informally named the "brown," "white," and "green" fans from the colors of their dominant sediments. They are composed dominantly of pelagic, carbonate, and volcanogenic turbidites, respectively, all derived primarily from the Walvis Ridge immediately to the south. The average rate of sedimentation for each of the brown and green fans was $2-3 \mathrm{~cm} / 1000 \mathrm{yr}$., but the frequency of (sandy) turbidites on the green fan $(1 / 2,500 \mathrm{yr}$.) was an order of magnitude higher than for the (muddy) brown fan $(1 / 25,000 \mathrm{yr}$.). Surprisingly, the brown fan sediments are more proximal than those of either the green or white fans. The primary controls on sedimentation in each case were different and included tectonic activity, paleogeography, sediment type, oceanic circulation, and sediment instability.
\end{abstract}

\section{INTRODUCTION}

Deep Sea Drilling Project (DSDP) Site 530 is located in the S.E. corner of the Angola Basin in the South Atlantic about $20 \mathrm{~km}$ north of the Walvis Ridge (Fig. 1). It lies on abyssal ocean floor about $250 \mathrm{~km}$ west of the shelf at a water depth of $4629 \mathrm{~m}$, and penetrated $1100 \mathrm{~m}$ of late Albian to Recent sediments overlying mid-Cretaceous seafloor basalts.

This part of the Angola Basin has received a varied suite of turbiditic and pelagic sediments since Albian time that reflect the combined influences of ocean spreading, northward plate drift, climate, ocean circulation, and base-of-slope location (Dean, Arthur, Stow this volume; Stow, this volume). Three sequences in particular show the dominance of downslope resedimentation and the probable construction of submarine fan accumulations (Fig. 2):

1) Brown fan: 0-270 m sub-bottom, Miocene-Recent

2) White fan: 470-695 m sub-bottom, MaestrichtianPaleogene

3) Green fan: $695-940 \mathrm{~m}$ sub-bottom, ?late Santonian-Campanian

These three sequences, each between 200 and $300 \mathrm{~m}$ thick and each deposited in a similar base-of-slope setting, are made up of markedly contrasting lithologies. The regional seismic stratigraphy, fan geometry, and lithological sequences will be compared in this chapter. More detailed sedimentary characteristics are described in the chapter by Stow (this volume).

\footnotetext{
${ }^{1}$ Hay, W. W., Sibuet, J.-C., et al., Init. Repts. DSDP, 75: Washington (U.S. Govt. Printing Office).
}

\section{SEISMIC STRATIGRAPHY}

Four main acoustic units can be recognized at Site 530 (Figs. 2, 3):

\begin{tabular}{cccl}
\hline $\begin{array}{c}\text { Acoustic } \\
\text { unit }\end{array}$ & Depth (m) & Seconds & \multicolumn{1}{c}{$\begin{array}{c}\text { Velocity } \\
(\mathrm{km} / \mathrm{s})\end{array}$} \\
\hline 1 & $0-270$ & $0-0.35$ & 1.526 \\
2 & $270-470$ & $0.35-0.6$ & 1.6 \\
3 & $470-790$ & $0.6-0.93$ & $1.83-2.154$ \\
4 & $790-1103$ & $0.93-1.20$ & 2.311 \\
\hline
\end{tabular}

These are separated by major discontinuities and form coherent units over the S.E. Angola Basin along a band $150 \mathrm{~m}$ wide north of the Walvis Ridge. Highly reflective ocean-floor basalts underlie Unit 4.

Acoustic Unit 1 is characterized in part by discontinuous and hatched reflectors and in part by more continuous, parallel reflectors. The discontinuous reflectors are mainly present close to the Ridge, together with transparent or disturbed lenticular zones below a slightly domed surface (Fig. 4). Minor progradation away from the Ridge is also evident on some profiles. The internal geometry and external form of Unit 1 suggest a series of small fans along the length of the Ridge, up to about $30 \mathrm{~km}$ in radius and composed of overlapping sediment lobes.

The northern slope of the Walvis Ridge is steep (up to $10^{\circ}$ ) and shows clear evidence of slumping in parts. The fans were probably constructed by sediments derived from these slumps, and from sediment basins on top of the Ridge through small channels across the northernmost basement high. At Site 530, acoustic Unit 1 corresponds to $270 \mathrm{~m}$ of calcareous and siliceous muds, marls, oozes, and debrites (debris-flow deposits) of Recent to late Miocene age ( $0-10$ m.y. ago) that make up the brown fan sequence. 


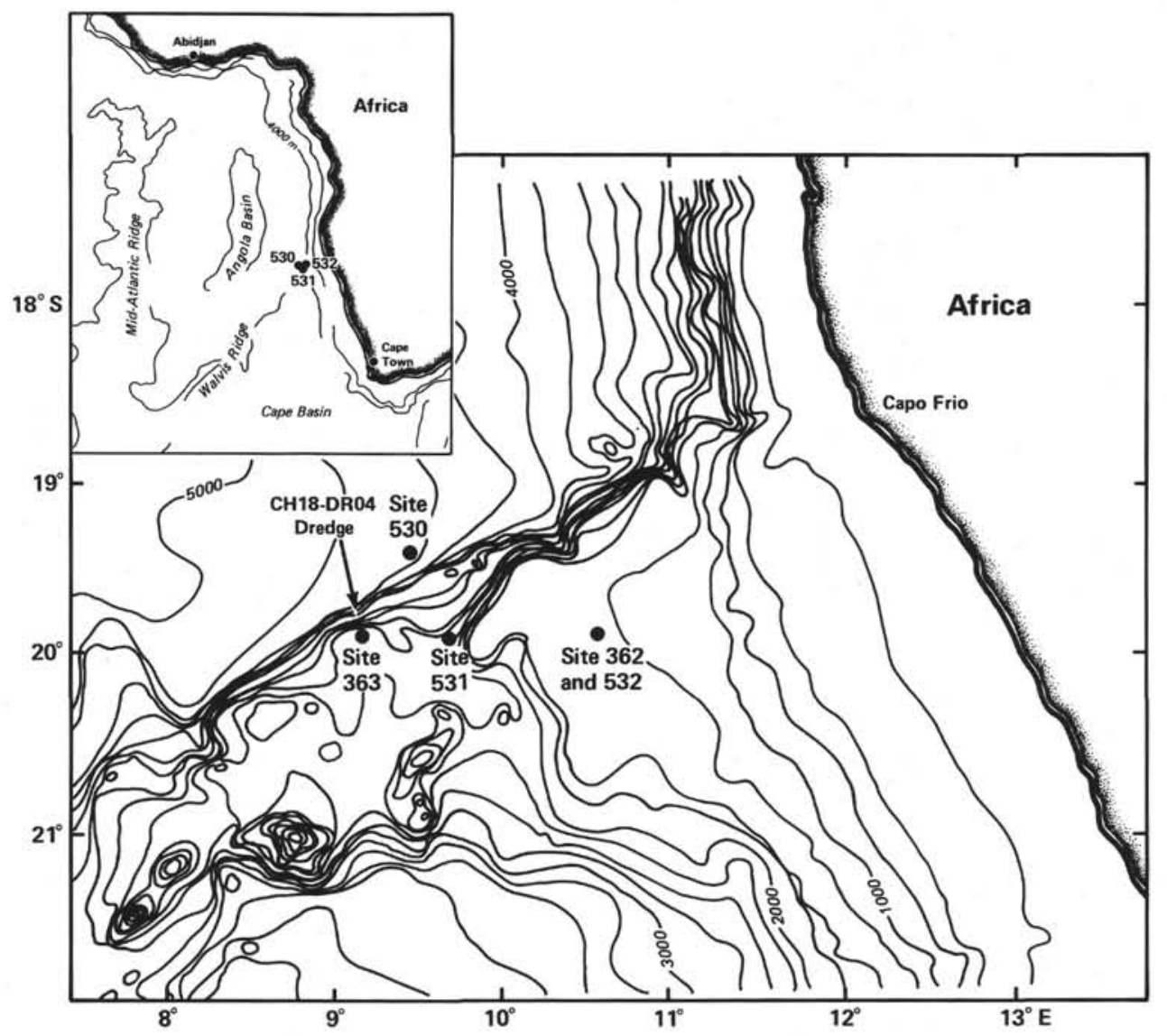

Figure 1. Location map and bathymetry of eastern Walvis Ridge and adjacent southern Angola Basin (depth contours in $\mathrm{m}$ ).

Acoustic Unit 2 is a transparent to faintly laminated layer of relatively uniform thickness across the whole area, overlying a major discontinuity. At Site 530 it corresponds to a red and green, carbonate-free mudstone sequence of Miocene-Oligocene age (10-37 m.y. ago).

Acoustic Unit 3 comprises strong, continuous parallel reflectors that gradually become less distinct northwards from the Ridge and less coherent or more widely spaced towards the African continental margin. The degree of stratification also decreases downwards into acoustic Unit 4, which is more faintly and discontinuously laminated (Fig. 5). Three discontinuities have been identified within these two units.

The top part of acoustic Unit 3, representing the white fan, corresponds to mudstone, marlstone, and thin-bedded hard limestones of Eocene-Campanian age (37-72 m.y. ago). The sequence is much condensed near the top and includes possible hiatuses within the lower Oligocene and Eocene, although core recovery was poor at this part of the well. The lower part of Unit 3 and the top part of Unit 4 correspond to mudstones, siltstones, and sandstones of the green fan sequence. A marked velocity increase at the base of Unit 3 coincides with the top of a series of closely spaced, thickly bedded sandstones. The lower part of Unit 4 comprises red, green, and black mudstones, marlstones, and thin-bedded siltstones of late Albian-Santonian age (about 80-102 m.y. ago).
At this depth on the seismic profiles a distinct fan geometry is difficult to distinguish. Very slight lenticularity is present in parts. The combined thickness of acoustic Units 3 and 4 varies markedly over an irregular ocean-floor basement and thickens generally towards the east. In places along the Ridge, north to south progradational reflectors are apparent, suggesting that some material was derived from the Ridge. From Site 530 the package of reflectors making up Unit 3 increases slightly in thickness towards the Ridge.

\section{GREEN FAN}

The green fan is Santonian-Campanian in age, about $250 \mathrm{~m}$ thick and was deposited in 8-10 m.y. Core recovery (Cores 61 through 86) was for the most part good, and the entire section was successfully logged in the bore hole with Gamma Ray, Caliper, Sonic, Induction, and Normal Resistivity tools.

Near the base, the sequence comprises numerous thin-bedded (1-10 cm thick) siltstone-mudstone turbidites. These overlie a thick basinal sequence of mudstones, marlstones, and black shales showing indications of both pelagic and turbiditic sedimentation. They pass upwards into thin and medium-bedded sandstonemudstone turbidites (up to $30 \mathrm{~cm}$ thick). Two upwardthickening, upward-coarsening units are present, each about $40 \mathrm{~m}$ thick. The upper unit is overlain again by mainly thinner-bedded turbidites that form an irregular 


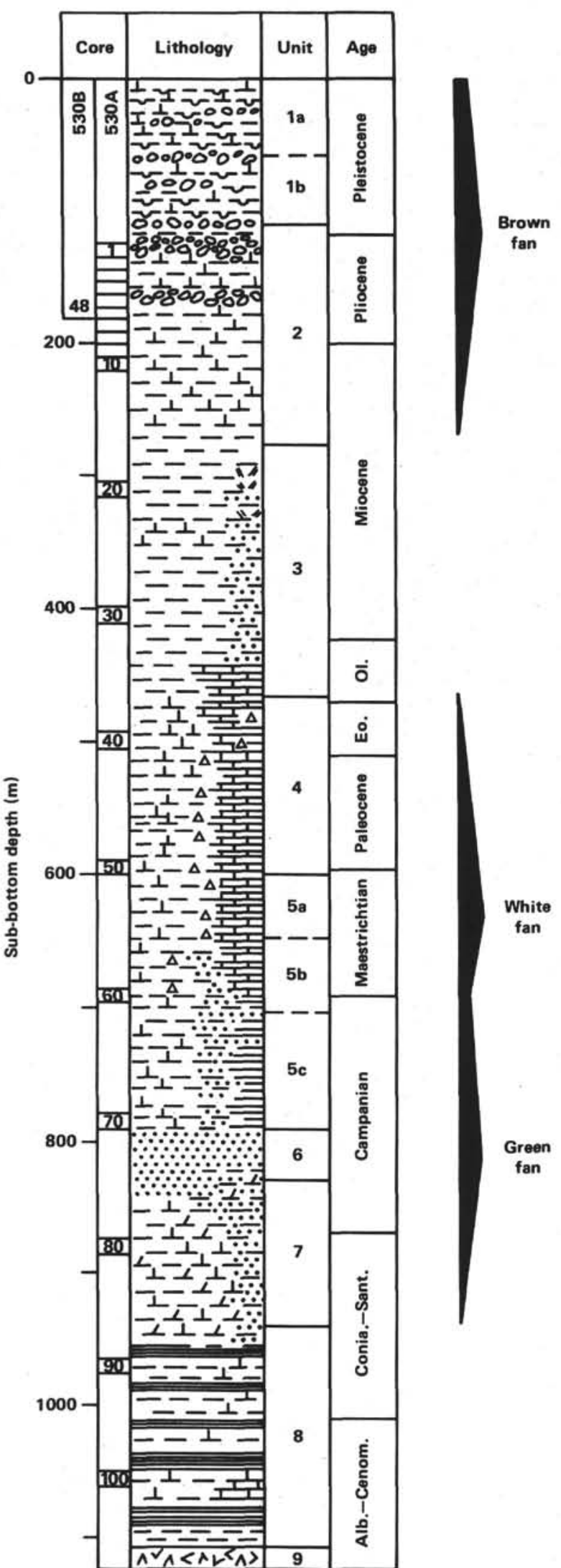

Figure 2. Stratigraphic and lithologic sequence at Site 530 (Holes A and B) showing the three fan sequences. (Revisions of stratigraphic ages are given in Steinmetz et al., this volume). upward-thinning and fining sequence approximately 20-25 m thick. This also comprises several slumped horizons that are a few centimeters to a meter thick.

In the middle of the sequence (Core 75) there is an abrupt change to thick and very thick-bedded sandstone and pebbly-sandstone turbidites. Individual beds are, in some cases, more than $3 \mathrm{~m}$ thick. These continue for about $35 \mathrm{~m}$ of section separated by only very thin mudstone intervals. The overlying $95 \mathrm{~m}$ of section shows an overall upward-thinning, upward-fining trend through medium-bedded, thin-bedded, and very thin-bedded turbidites. Superimposed on this general trend are smaller oscillations in bedding thickness.

These lithological features are summarized in Figure 6 , which shows the variation in turbidite thicknesses through the green-fan sequence, as well as the percentage of sandstone per section of core. The overall thickening-upward then thinning-upward trends are also clearly seen on the continuous wireline log records (Fig. 7). A gamma count averaging $25 \mathrm{API}$ in the fine-grained turbidites near the base of the green fan (Core 85) decreases to about 15 API in the sandier turbidite sections, and then decreases sharply to between 5 and 10 API with the incoming of the massive sandstones in Core 75 . The gamma count slowly picks up again to 20-25 API over the upper $90 \mathrm{~m}$ of section. The Sonic Log shows a mirror image pattern with low values (1.5$1.7 \mathrm{~km} / \mathrm{s}$ ), where mudstone turbidites dominate, and higher values $(2.0-2.2 \mathrm{~km} / \mathrm{s})$ in the sandier sections. The actual values are consistently lower than our laboratory data for the rocks and probably reflect disturbed borehole conditions with a shallow depth of investigation by the Sonic tool.

The thick sandstone section (800-835 m depth) is particularly clear on all logs. Another peak at about 720 $\mathrm{m}$ depth on the Sonic and Conductivity logs is associated with a package of thin and medium-bedded sandstones that have a pervasive carbonate cement. The further increase in Sonic and conductivity log readings and corresponding decrease in gamma count from about 700 $\mathrm{m}$ upwards is related to the incoming of white fan carbonate sediments.

The systematic lithological changes noted above, associated with characteristic wireline log patterns, can best be interpreted in terms of deposition on a submarine fan (Figs. 6 and 7) (Mutti and Ricci Luccli, 1972, 1975; Mutti, 1977; Walker and Mutti, 1973; Walker, 1978). The lowest part of the section may represent fan fringe turbidites prograding onto the Late Cretaceous S.E. Angola Basin plain. The two upward-thickening units are interpreted as lower to mid-fan lobes, with one or two small channel-like deposits and associated slumps at the top of the second lobe. The thick-bedded sandstones represent middle to upper-fan channel deposits, overlain by a thick fining-upward channel-fill sequence.

\section{Lobes and Channels}

Although the seismic reflection profiles are on too small a scale to permit the resolution of more than the broadest fan geometry, detailed core and log analysis 


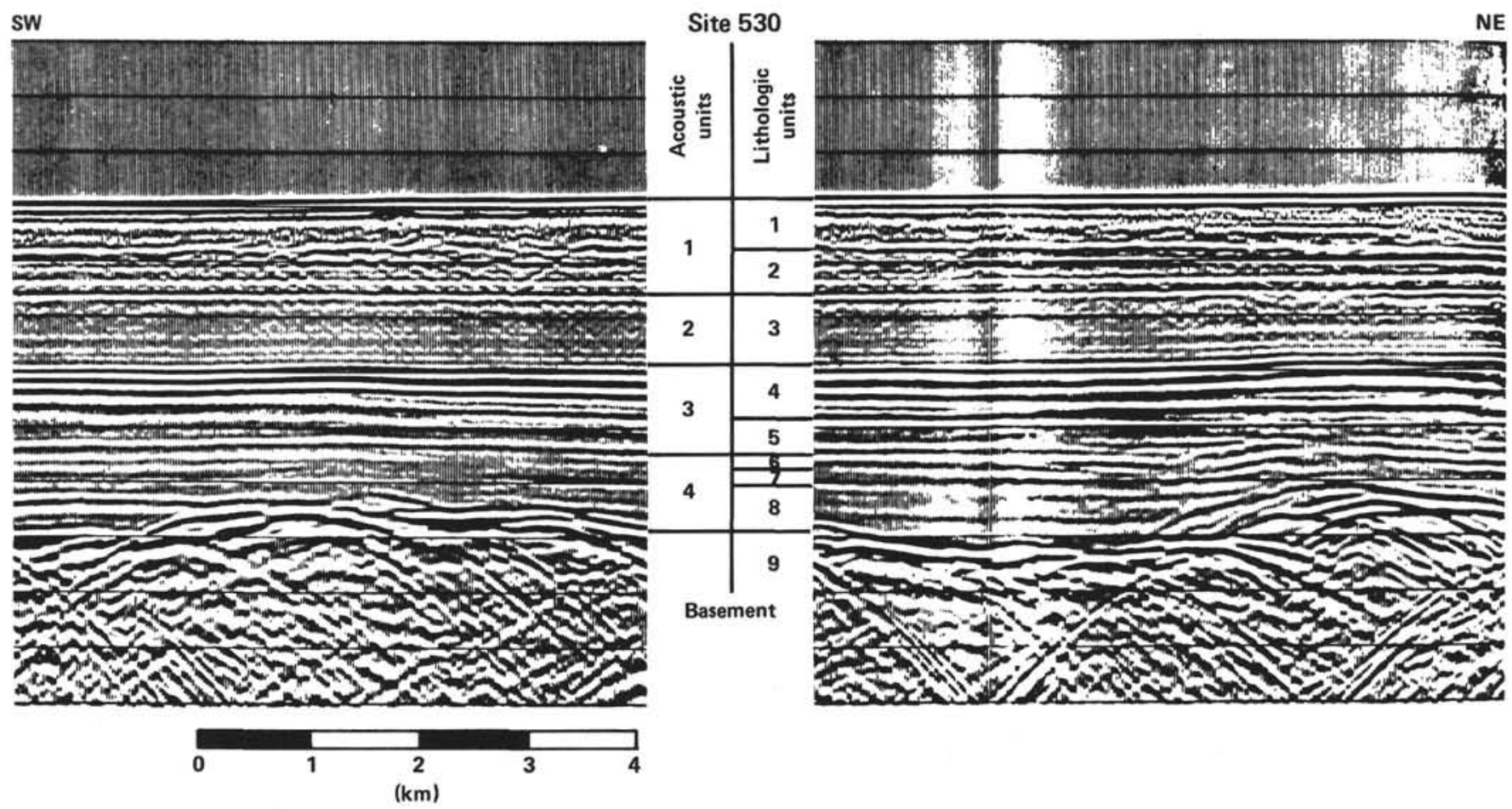

Figure 3. Seismic reflection profile through Site 530 showing acoustic and lithologic units.

does reveal distinctive lobe and channel characteristics. Figure 8 shows a lobe sequence developed through Cores 76-81. Near the base, the turbidites average 1-5 $\mathrm{cm}$ in thickness with less than $1 \mathrm{~cm}$ very fine-grained (63-125 $\mu \mathrm{m})$ sand. Many of these start with Bouma C or D structural divisions (Bouma, 1962). There are also pure mudstone and very thin-bedded siltstone turbidites with structures similar to those described by Stow and Shanmugam (1980). On average, there are about 20 recognizable turbidite units per meter of core, the rest being bioturbated mudstone (part turbidite, part pelagite).

Upwards through the lobe sequence, the average turbidite thickness and grain size increase very slightly (2-8 $\mathrm{cm}, 75-150 \mu \mathrm{m})$, the thickness of the sandstone layers increases (1-2 cm), and hence, too, the percentage of sandstone per meter. Towards the top, the number of turbidites per meter decreases to about $12-14$, and there are more medium-thick beds $(10-30 \mathrm{~cm})$ having a basal grain size of about $250 \mu \mathrm{m}$. Superimposed on these general trends are minor fluctuations in turbidite thickness and grain size.

Overlying this upward-thickening, upward coarsening trend there is a return to finer-grained, thinnerbedded turbidites, averaging 20 or so per meter. These contain isolated thick sandstones $(20-60 \mathrm{~cm}$, basal grain size $250-750 \mu \mathrm{m})$ and extensive slumped horizons. It is only in the thick and medium-thick beds towards the top of the sequence that Bouma B structural divisions occur at the base of the turbidites.

Figure 9 shows the main channel sequence represented in Cores 71-75, and the beginning of channel fill in Cores 68-70. The channel sandstones cut sharply into the underlying thin-bedded turbidite, mudstone-dominated sequence. There are a series of 8 to 10 very thick
(1-3.6 m) sandstone beds separated by thin mudstone horizons or by thin $(<10 \mathrm{~cm})$ turbidites. These thickgraded beds commonly have a mean size near the base of 250-750 $\mu \mathrm{m}$, and begin with Bouma A structural divisions in top cut-out sequences. Probably amalgamation surfaces are also present. These are followed by 10 or more thick $(0.8-1.5 \mathrm{~m})$ sandstones separated by rather thinner turbidites, but still with $80-95 \%$ sandstone per core length.

The overlying cores, interpreted as representing channel-fill immediately after the main phase of channel activity, comprise about 10 thin- to medium-bedded $(5-15 \mathrm{~cm})$ sandstone turbidites per meter of section inter-bedded with very thin mudstone and siltstone turbidites and intermediate bioturbated mudstones and marlstones. The sandstones are still medium to coarsegrained at the base $(250-750 \mu \mathrm{m})$ and begin with either Bouma A or B divisions.

The Sonic and Gamma logs closely mirror the general lobe and channel lithological trends noted above (Figs. 8 and 9). It is therefore possible to infer sediment types where there has been no core recovery-for example, there appears to be an interval of a few meters of muddy sediments near the top of the channel sands, between Cores 71 and 72. The two high sonic log peaks without noticeable Gamma log responses near the bases of Cores 78 and 79 may be related to diagenetic effects (e.g., carbonate cement) rather than to thick sandstone beds. It is clearly not possible to match the logs with the cores on a bed-by-bed basis.

\section{Source and Rates of Sedimentation}

The sandstone and siltstone turbidites throughout the green-fan sequence are composed dominantly of volcanogenic material (Stow and Miller, this volume). This 

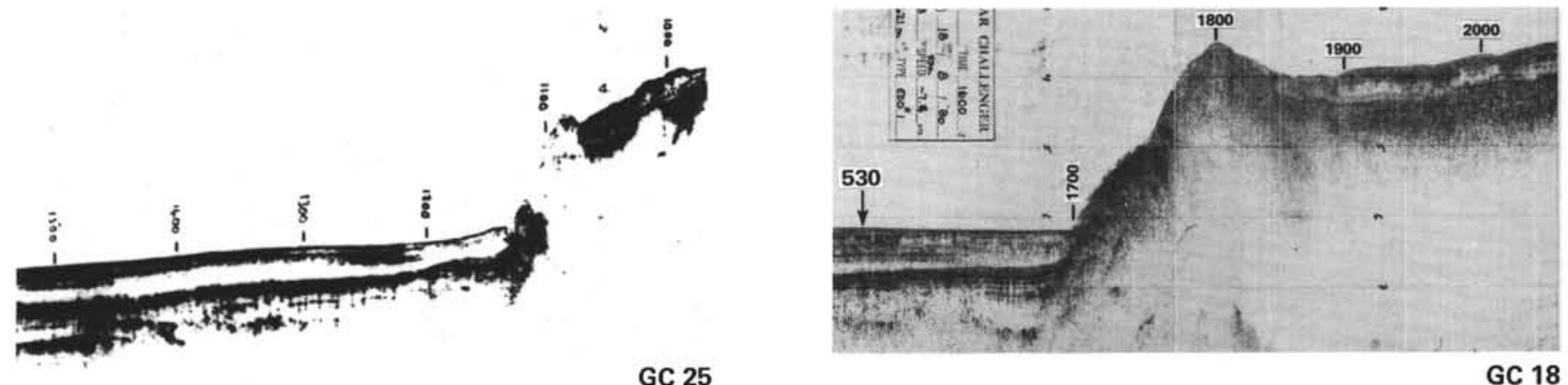

GC 25

GC 18
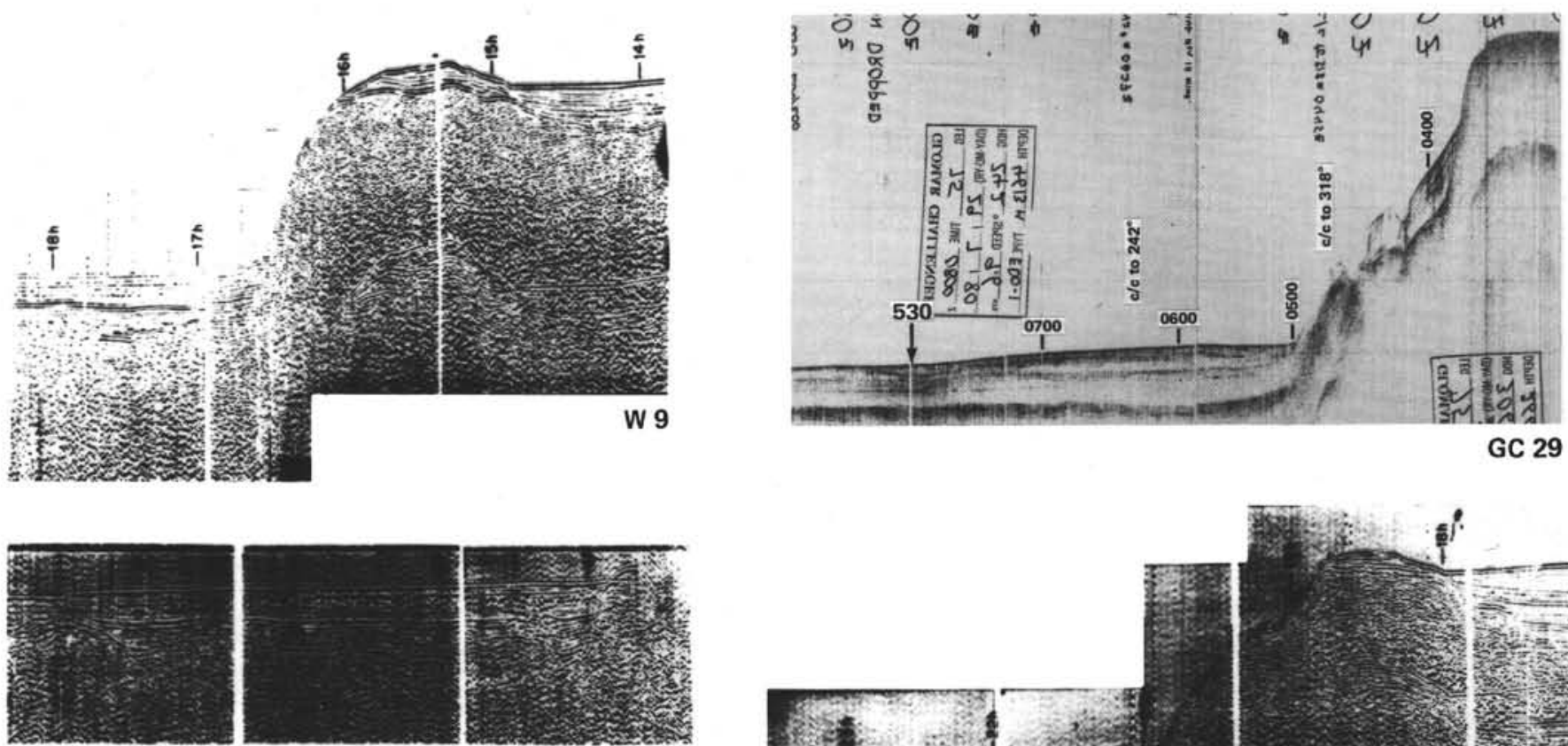

W 2
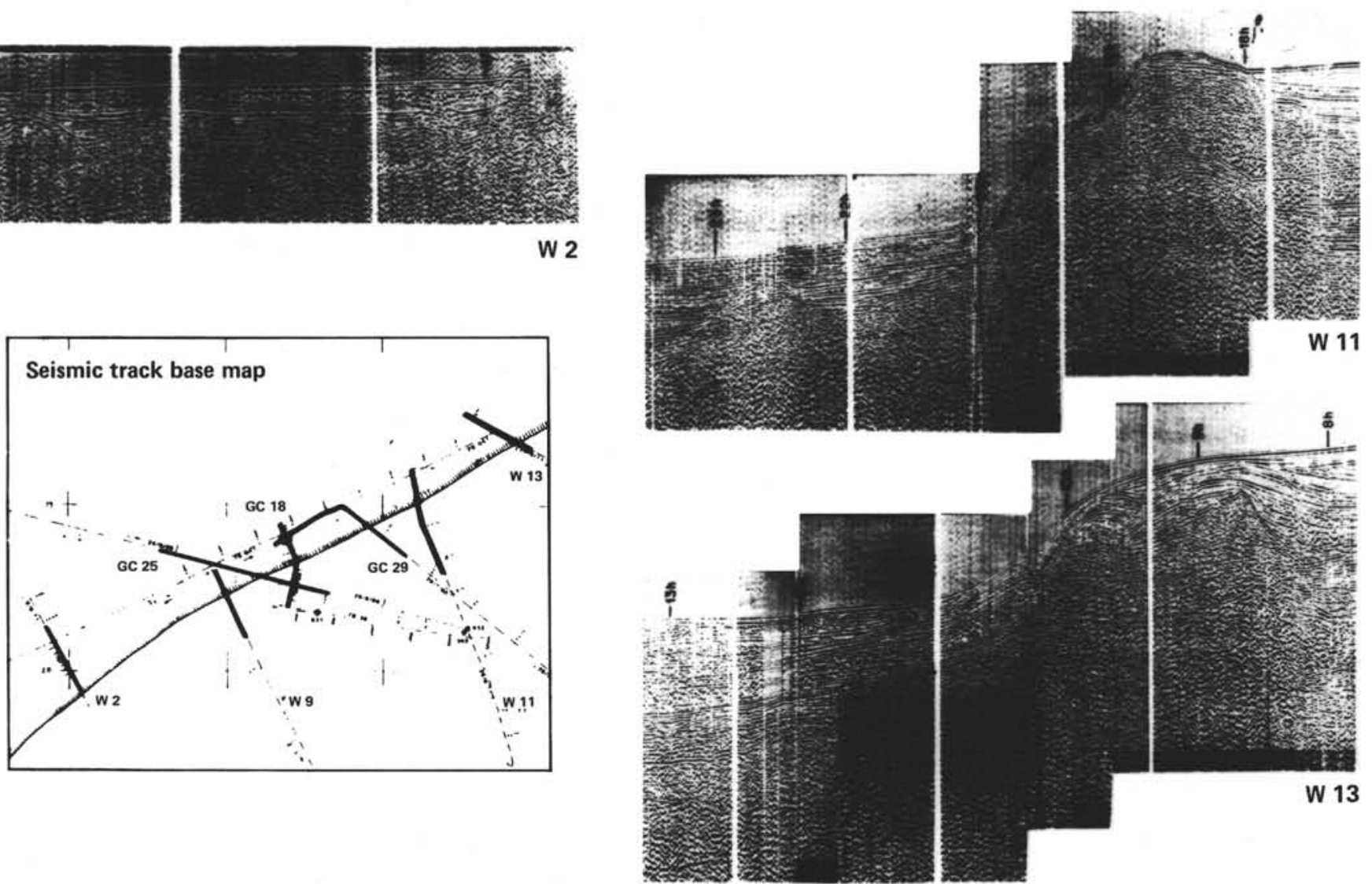

Figure 4. Seismic reflection profiles showing indistinct, chaotic; and lenticular characteristics of acoustic Unit 1 (equivalent to brown fan sequence). (See Fig. 3 for seismic units.) 

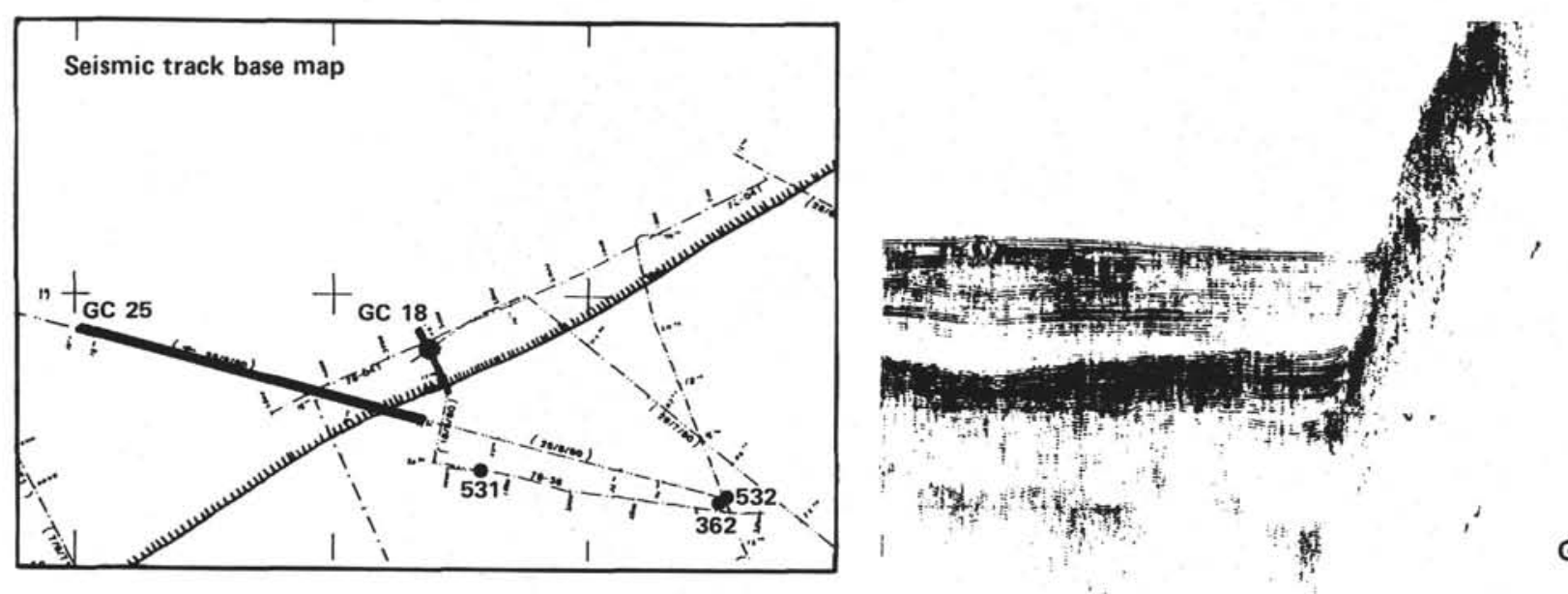

GC 18

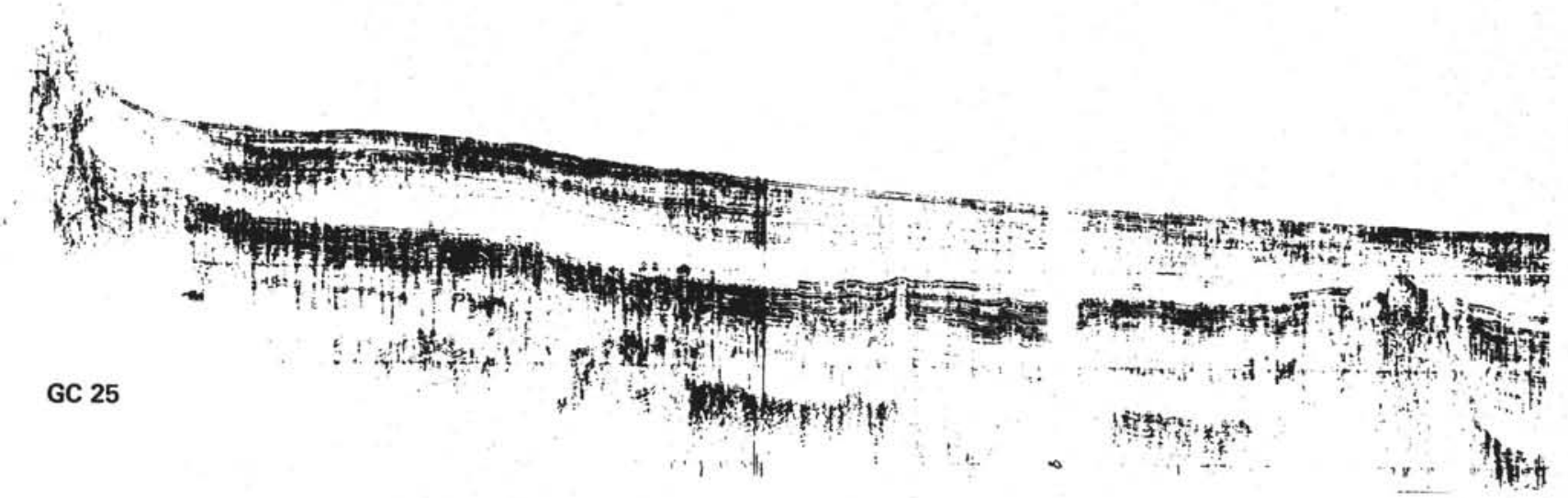

Figure 5. Seismic reflection profiles showing seismic facies characteristics of acoustic Units 3 and 4 (comprise white and green fans). (See Fig. 3 for seismic units.)

includes glassy, vesicular, and microcrystalline basalt fragments which have commonly been highly altered, devitrified, and reworked as sand-sized grains. Iron oxides are common, and minor minerals include quartz, feldspar, opaques, pyroxenes, and rare glauconite. The volcanogenic sands are mostly cemented by pervasive sparry calcite or micrite. Some of this carbonate shows evidence of a biogenic origin (foraminifers, shell fragments, etc.).

Towards the base and top of the green-fan sequence, the carbonate cement is more abundant than the volcanogenic debris, biogenic remains are more common, and, in some beds, quartz becomes an equally important component. The clay mineralogy throughout is dominated by smectite and mixed-layer smectite minerals with associated chlorite and illite. (Maillot and Robert, this volume). This assemblage is probably derived mainly from volcanic rocks and from the alteration of volcanogenic debris.

The most probable source of the green fan sediments appears to be the Walvis Ridge immediately adjacent to the south, presumably via a transverse (south-north) feeder canyon. Dredge samples from this part of the Ridge recovered both ferruginous and quartz-bearing alkali basalts as well as pumice and pyroclastic material (Hekinian, 1972). DSDP Site 363 did not reach base- ment volcanics, but there was evidence of major erosion or nondeposition from late Cenomanian-early Campanian times and of a volcanic provenance for Late Cretaceous sediments (Bolli, Ryan et al., 1978). Further to the southwest, DSDP Leg 74 drilled five closely spaced sites from the crest of the Ridge northwards into the Angola Basin (Moore et al., 1981). The basement complex (early Campanian-Maestrichtian) comprised interlayered calcareous and volcanogenic sediments and basalts. This is overlain by Campanian-Maestrichtian volcanogenic sandstones and mudstones interbedded with chalks and limestones, which commonly show evidence of turbidite deposition.

There have been several hypotheses for the origin of the Walvis Ridge by uplift (Ewing et al., 1966), transform faults (Francheteau and LePichon, 1972), or hot spots (Goslin and Sibuet, 1975). From these models, it appears probable that there was a period of active tectonism and volcanism during the Late Cretaceous. This activity led to the redeposition of volcanogenic sediments into the Angola Basin and to the growth of the green fan.

Our best estimate of the overall sedimentation rates for the green fan are $1-3 \mathrm{~cm} / 1000 \mathrm{yr}$. (Site 530 summary chapter et al., this volume). However, with individual units of over $3 \mathrm{~m}$ being deposited "instantaneously," 


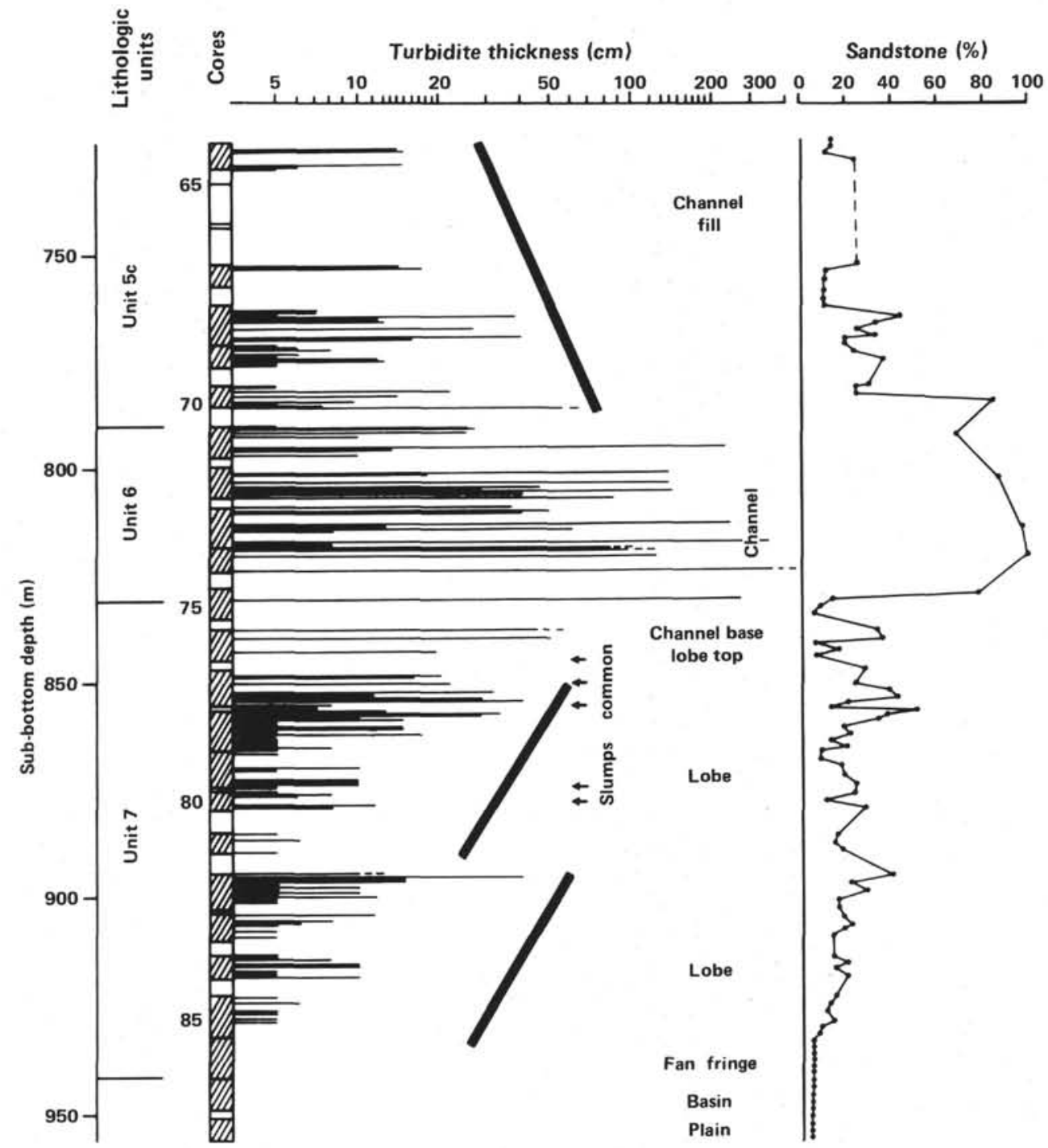

Figure 6. Turbidite thickness and sandstone percentage through the green-fan sequence (Cores 64 through 88).

the sedimentation rates for some intervals must have been several orders of magnitude greater. Similarly, the estimated 3000 turbidites deposited in 8 m.y., a rate of one turbidite per 2000 to 3000 yr., understates the variability of the rate of deposition through the period of fan growth.

\section{WHITE FAN}

The white fan forms a continuous sequence from the underlying green fan, ranges in age from Maestrichtian to Eocene (about 30 m.y.), and has a thickness of some $225 \mathrm{~m}$. Core recovery (Cores 37 through 60 ) for this interval was less (average $35 \%$ ) than for any other part of the well and, unfortunately, our logging suite only covers the lower $70 \mathrm{~m}$ of the sequence.

The lithological variability of this sequence is notable. Mudstone and marlstone are the most abundant lithology and both are commonly highly bioturbated. Interbedded with these "background" sediments are four distinct turbidite types-three of which are mainly calcareous and one of which is siliciclastic. There are thin-bedded $(2-4 \mathrm{~cm})$ calcareous mudstone turbidites, thin- to medium-bedded $(5-25 \mathrm{~cm})$ calcilutite-mudstone turbidites, and medium- to thick-bedded $(5-60 \mathrm{~cm}) \mathrm{cal}-$ carenite-calcilutite-mudstone turbidites. The siliciclastic turbidites are very thin to thin-bedded $(<1-3 \mathrm{~cm})$, quartz-rich, fine-grained muddy sandstones. The mean grain size of the calcarenites varies from about 100 to $1000 \mu \mathrm{m}$, and maximum size of individual clasts ranges up to about $15 \mathrm{~mm}$.

From the base through about $50 \mathrm{~m}$ of section there is a somewhat irregular upward increase in the thickness and grain size of turbidite beds, followed by a decrease over the next $30-40 \mathrm{~m}$ (Fig. 10). Although there are many gaps in core recovery, this pattern is also evident on the wireline logs (Fig. 7) and is shown in more detail in Figure 11. The thicker calcarenite turbidites may show complete Bouma sequences (ABCDE) or partial sequences (ABE, BCE, etc.). The medium-thick-bedded turbidites tend to show base-cut-out Bouma sequences. 


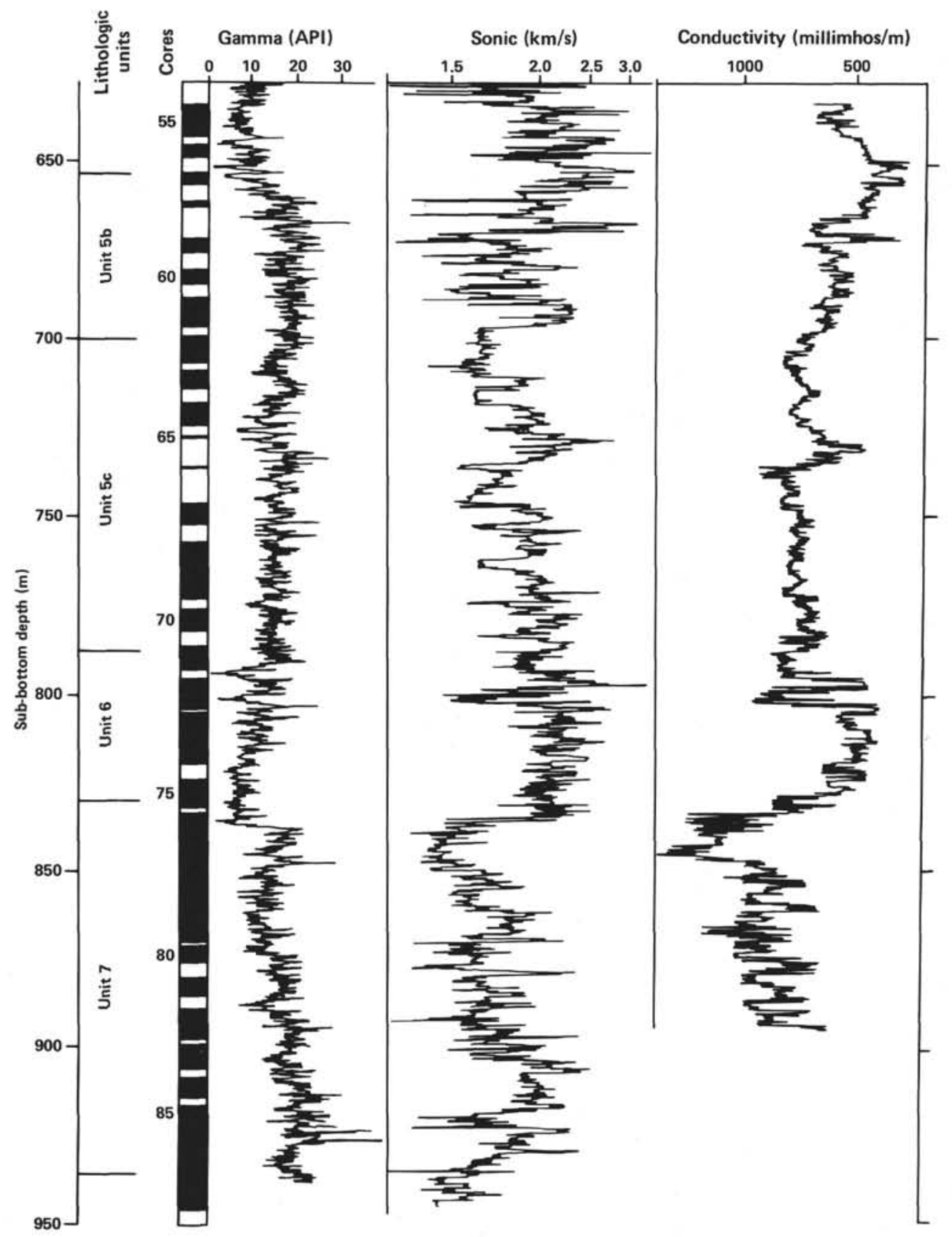

Figure 7. Wireline log characteristics and lobe-channel development through the green fan and part of the white fan sequences.

The upper $150 \mathrm{~m}$ of the sequence appears to show three similar oscillations in bed thickness and grain size, each covering about $50 \mathrm{~m}$ of section (Fig. 10), although without log control these are clearly less distinct. Mediumand thick-bedded calcilutite turbidites are more common in the upper 60-70 m, whereas thin-bedded sandstone turbidites are more common in the lower $70-80 \mathrm{~m}$.

Interpretation of this sequence as part of a submarine fan is equivocal, because it is too deep in the seismic records to show any very clear geometric form. It is, however, composed of redeposited material in numerous turbidite beds, which appear to be arranged in discrete thickening-upward to thinning-upward packages, each from 40 to $80 \mathrm{~m}$ thick. These may be interpreted as (?)mid-fan lobes prograding over lower-fan or outer-fan lobes over basinal sediments.

\section{Source and Rates of Sedimentation}

The calcarenites are composed of mainly shallow-water carbonate debris, including benthic reef foraminifers and fragments of lamellibranchs, echinoids, bryozoa, and calcareous algae, mixed with volcanic rock fragments, quartz, feldspar, and other mineral grains (Stow and Miller, this volume). They are commonly cemented by both micrite and sparry calcite, and more rarely by silica replacing calcite. The calcilutites and mudstones 


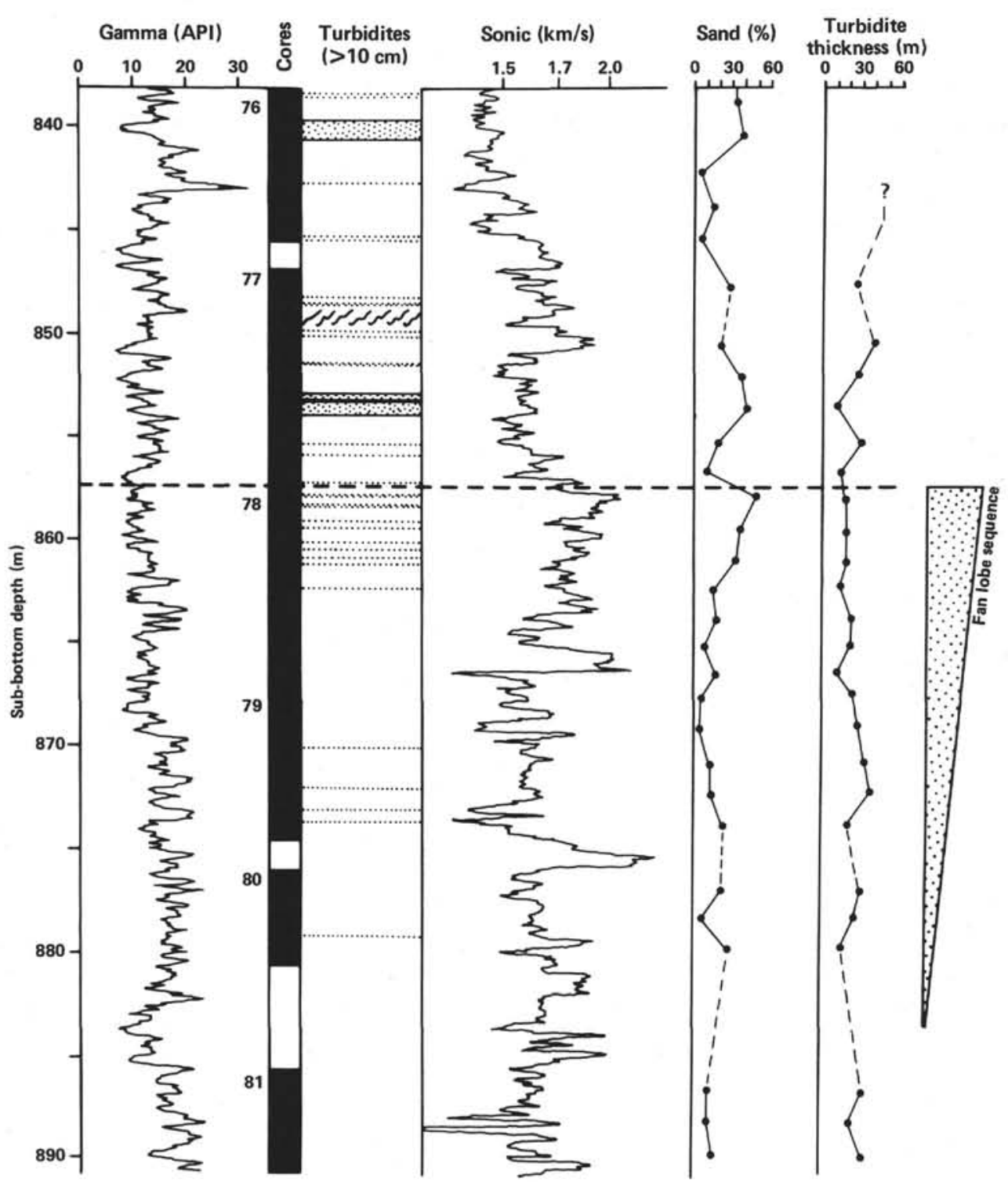

Figure 8. Detail of green-fan lobe sequence (Cores 76-81). Wireline log and lithological characteristics.

are composed of calcareous microfossils, unspecified carbonate, quartz-palagonite silt, and a clay assemblage dominated by illite with secondary smectite.

Nearby Sites 362 and 363 on the Walvis Ridge also have carbonate-rich sequences of Maestrichtian-Paleocene-Eocene age (Bolli, Ryan et al., 1978). These include thick calcarenite turbidites and slumped zones at Site 362, and thinner-bedded calcarenites and calcilutites also showing evidence of turbiditic deposition at Site 363. Further S.W., Site 526 on the crest of Walvis Ridge encountered shallow-water calcareous sands of Palaeogene age, whereas sites just off the Ridge crest recovered calcarenite turbidites, chalks, and oozes of the same age (Moore, et al., 1981).

It appears most probable that one or more volcanic islands along the Walvis Ridge were emergent and ringed by reefs from the end of Cretaceous through $\mathrm{Pa}$ laeogene, and that these islands and reefs supplied the coarse-grained shallow-water carbonate debris mixed with minor volcanics both to the Angola Basin (Site 530) and to basinal areas on the Ridge itself (Sites 362 and 363). The finer-grained quartz-sand turbidites and the illite component of the clay fraction were more likely derived from the African continental margin.

Average sedimentation rates for the complete white fan sequence are very low ( $<1 \mathrm{~cm} / 1000 \mathrm{yr}$.). However, from the rather incomplete biostratigraphic record there appear to have been marked departures from the average, and also the possibility of hiatuses during early and late Eocene time. The rate is highest in the Maestrichtian, averaging about $2 \mathrm{~cm} / 1000 \mathrm{yr}$. but with a peak several times that rate during deposition of the thicker calcarenites (Cores 55-57). The rate is similar but not quite as high (average $1.5 \mathrm{~cm} / 1000 \mathrm{yr}$.) during the late Paleocene, and appears lowest during the Eocene. Clearly, as with the green fan, "instantaneous" rates are orders of 


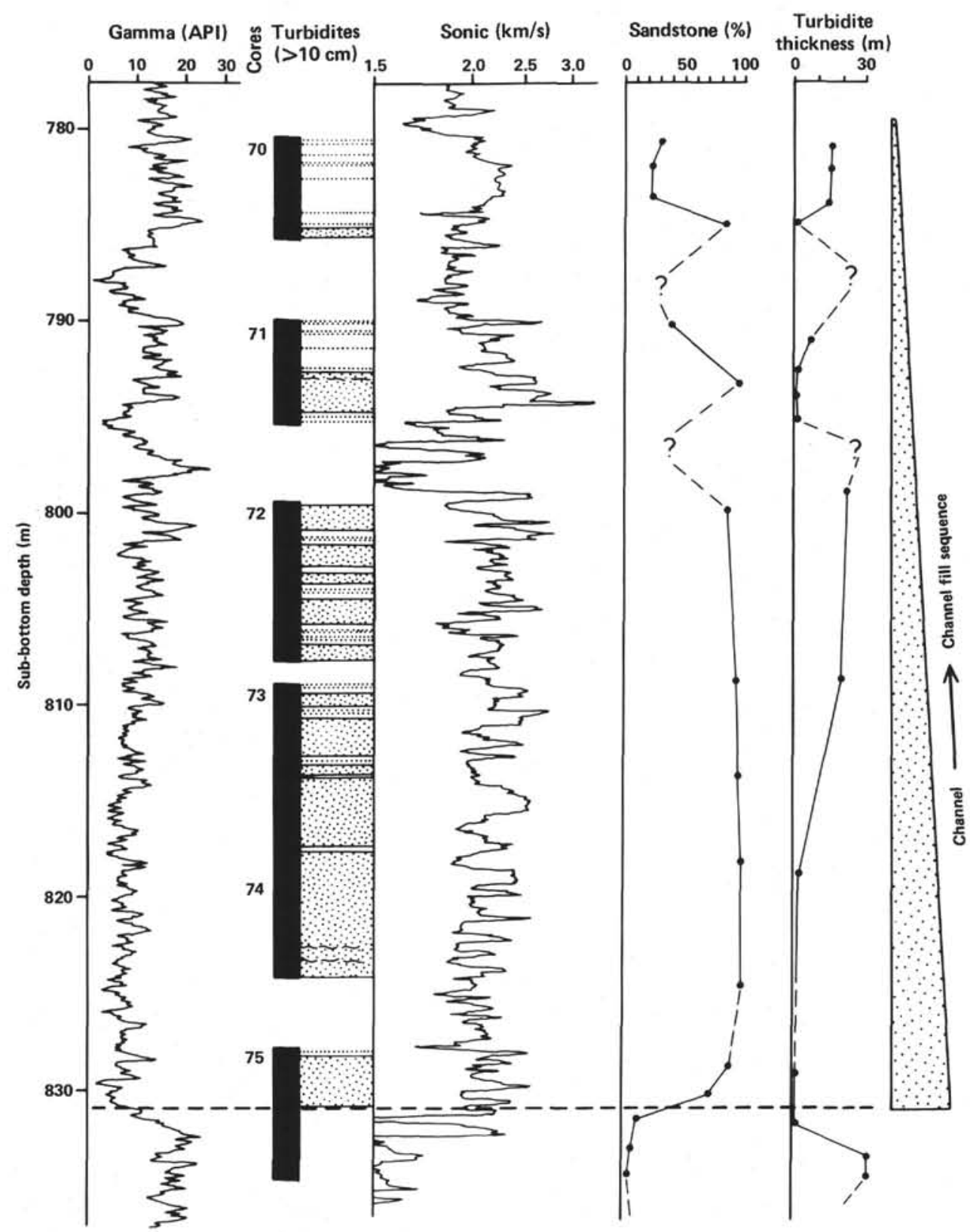

Figure 9. Detail of green-fan channel sequences (Cores 70-75). Wireline log and lithological characteristics.

magnitude higher, with single events depositing over 60 $\mathrm{cm}$ of sediment. Recovery is inadequate for estimating the frequency of turbidity currents.

\section{BROWN FAN}

Perhaps most interesting and most unusual of the three fan sequences encountered at Site 530 is the brown fan, which began its development in the late Miocene (about $10 \mathrm{~m} . \mathrm{y}$. ago) and is probably still active today. It is about $270 \mathrm{~m}$ thick and core recovery was mostly very good, but no wireline logs were successfully completed in the open hole over this interval. The upper $180 \mathrm{~m}$ were cored with the hydraulic piston corer (HPC) in Hole 530B (Cores 1-48). Conventional coring in Hole $530 \mathrm{~A}$ recovered the section from $125-270 \mathrm{~m}$ (Cores 1-16).
Prior to the onset of brown fan growth, the Oligocene through Miocene was a period of extremely slow sedimentation or erosion in the southeastern Angola Ba$\sin$. The carbonate compensation depth was sufficiently high to prevent the preservation of calcareous tests. The sediments are mainly composed of red and green "pelagic" clays, muds, and palagonite silt. Infrequent turbidity currents deposited thin (average $1-4 \mathrm{~cm}$, maximum $10 \mathrm{~cm}$ ) mud turbidites in the basin. Seismic facies mapping suggests that the dominant source of terrigenous material at this time was the African continent to the northeast.

Through the lower $120 \mathrm{~m}$ of the brown fan, thin to medium-bedded $(5-30 \mathrm{~cm})$ mud-marl turbidites form $20-30 \%$ of the section, marl and ooze pelagites form $50-70 \%$, and debris-flow deposits (debrites) approx- 


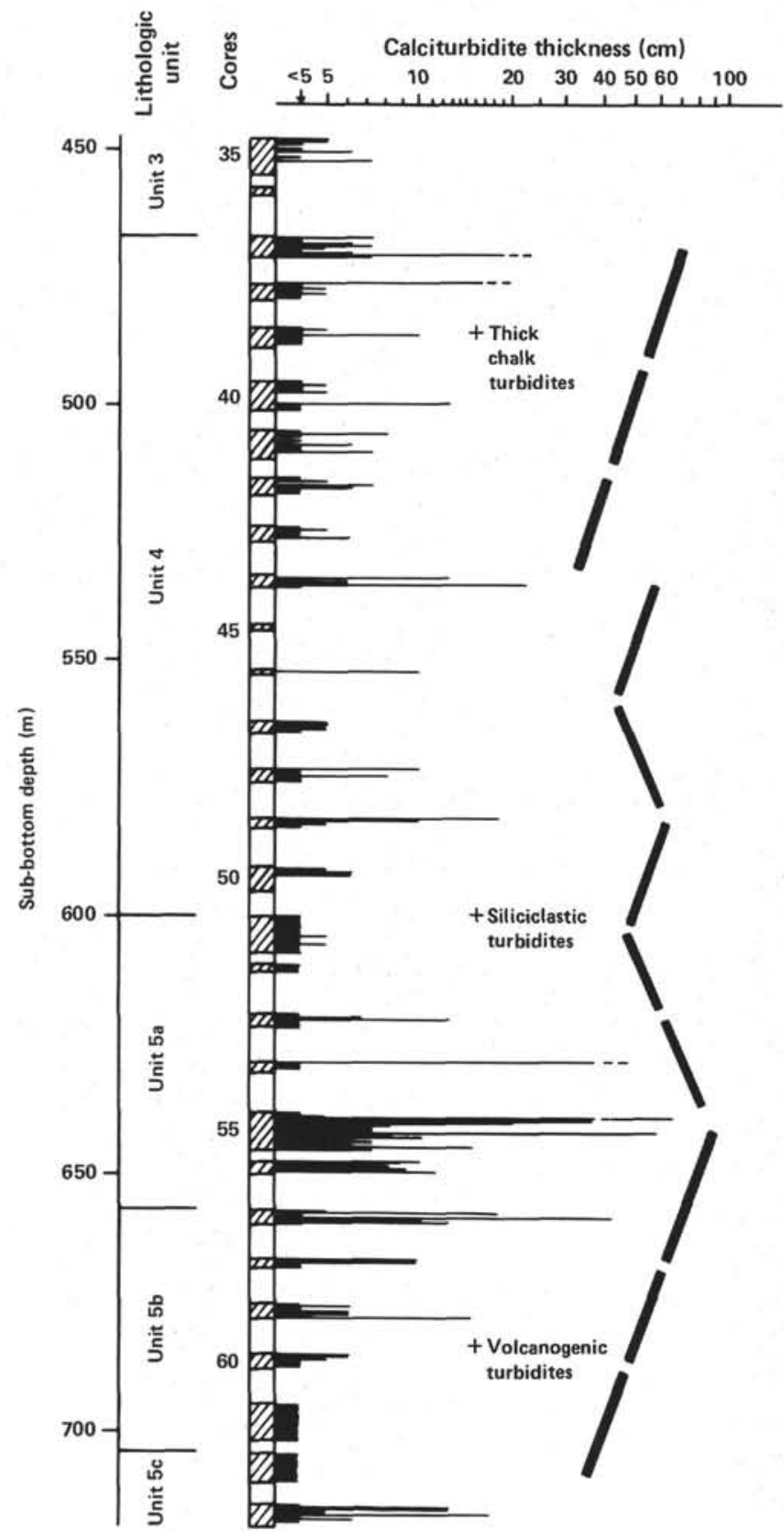

Figure 10. Turbidite thickness through the white-fan sequence (Cores $37-60$ ).

imately $10 \%$. The turbidites commonly have a very thin silt-laminated base, grade rapidly into a biogenic mud, and are extensively mixed with the overlying ooze by bioturbation and burrowing. There are numerous thinbedded $(<5 \mathrm{~cm})$ turbidites throughout, but an overall increase in the number of thicker beds (up to $35 \mathrm{~cm}$ ) is evident through the first $80-90 \mathrm{~m}$ of section, followed by a slight decrease over the next $30-40 \mathrm{~m}$ (Fig. 12). Associated with this upward-thickening trend is a parallel increase in the number and (?)thickness of debrites. These comprise varicolored, semilithified, and semirounded mud clasts and rare basalt pebbles in a mudmarl matrix (Stow et al., this volume). They are generally less than $0.5 \mathrm{~m}$ thick near the base of the section,

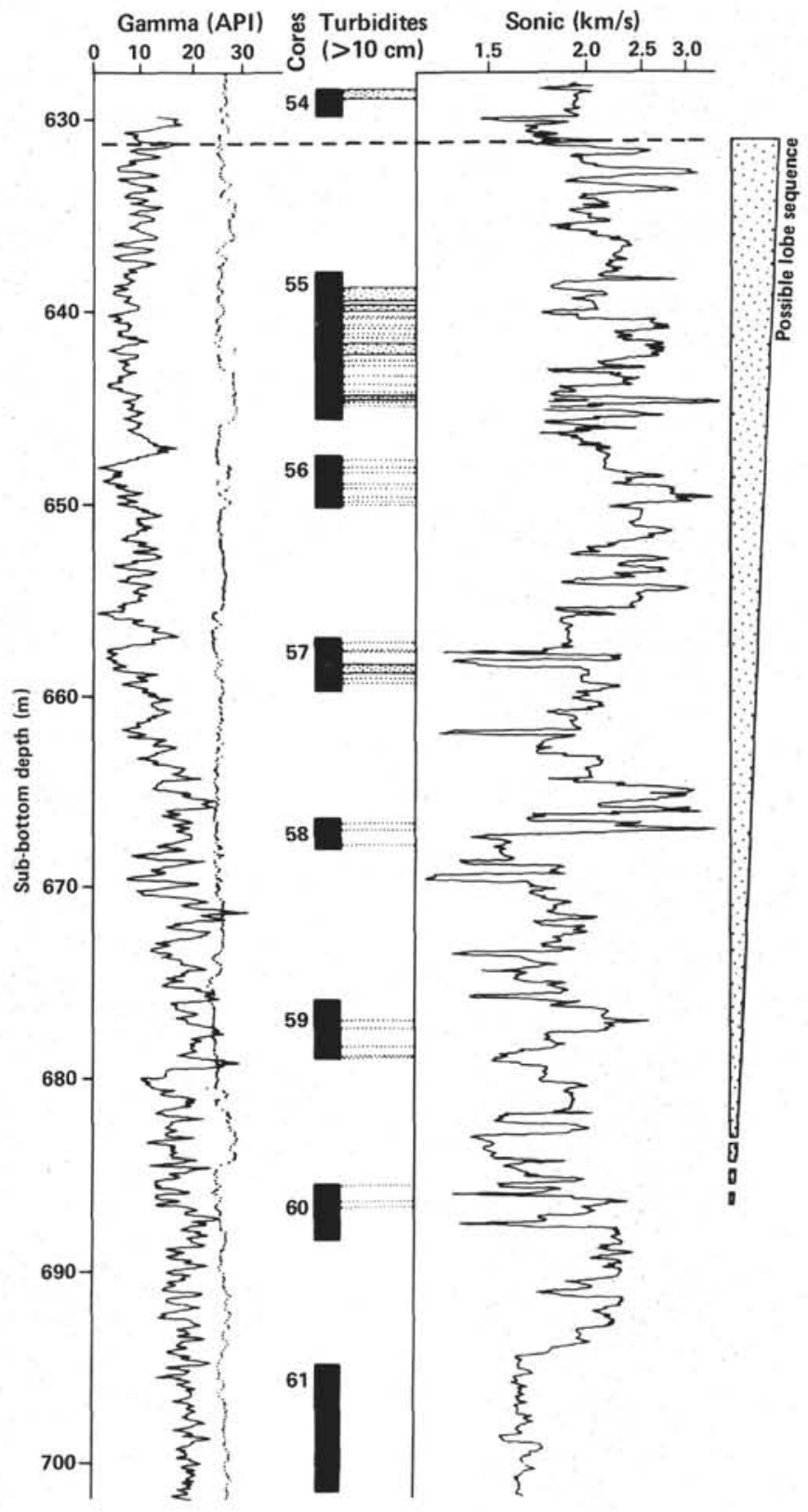

Figure 11. Detail of white fan lobe sequence (Cores 54-61). Wireline log and lithological characteristics.

several meters thick in Cores 8 and 9 (Hole 530A) and probably $9.5 \mathrm{~m}$ thick in Cores 45-47 (Hole 530B).

Overlying this lower part of the brown fan sequence there are about $40 \mathrm{~m}$ of thick debris-flow deposits (debrites) with one single debrite that may be as much as $32 \mathrm{~m}$ thick. Above this there are $50 \mathrm{~m}$ of rather disturbed marls, sarls, and oozes, and then a 5-m thick debrite (Fig. 12). The $50 \mathrm{~m}$ section sandwiched between debrites shows several features that indicate sedimentdisturbance layering inclined at up to $45^{\circ}$, small-scale overturned folds, irregular sediment mixing-but with retention of some degree of internal sediment coherence. The whole of this zone (Hole 530B, Cores 16-27) is tentatively interpreted as a thick slumped sediment mass, closely associated in time and mechanism with the adjacent debrites. Physical property measurements in 


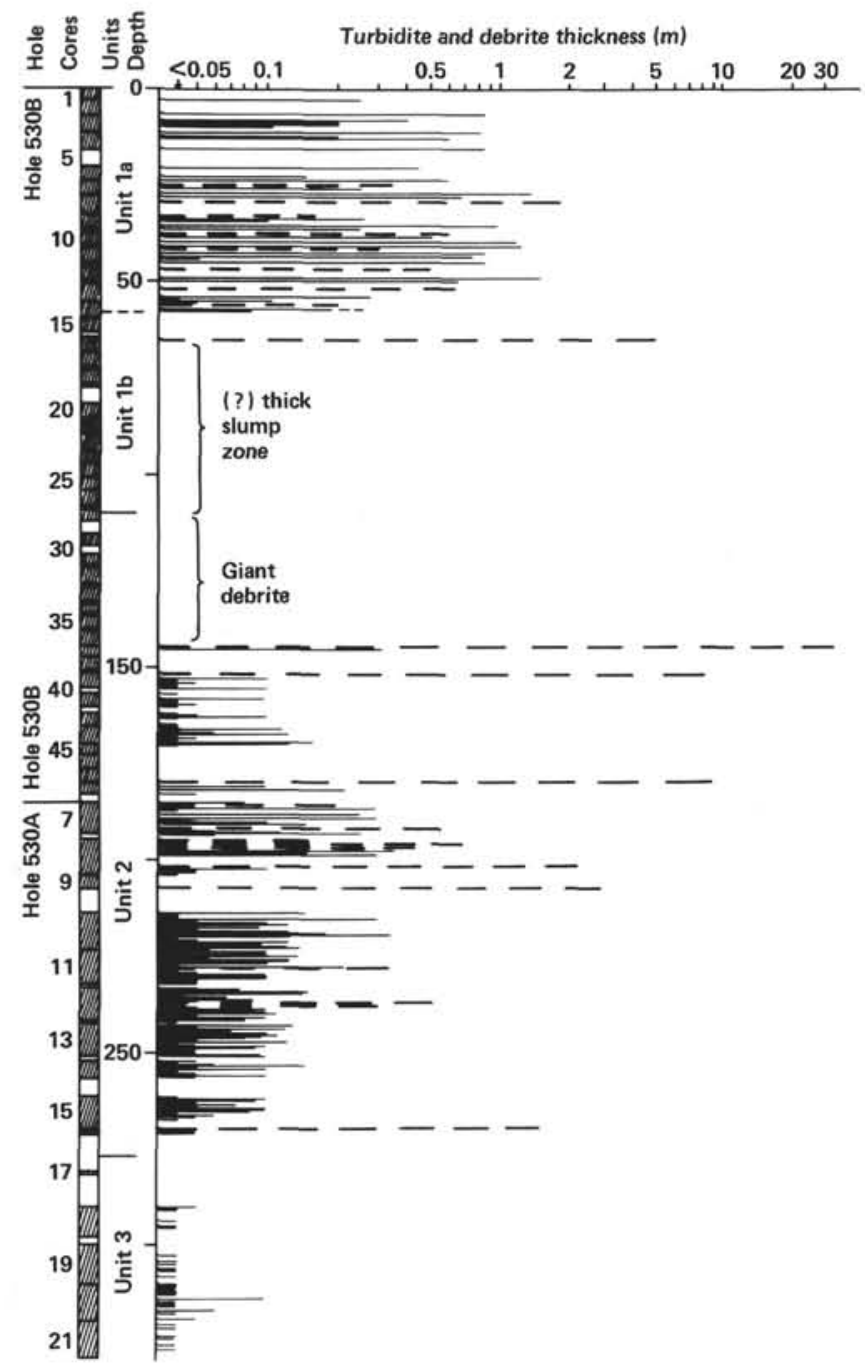

Figure 12. Turbidite and debrite thicknesses through the brown-fan sequences (Hole 530B, Cores 1 to 48; Hole 530A, Cores 1 to 16 ). (Solid lines $=$ turbidites, dashed lines $=$ debrites.)

Hole 530B (Site 530 summary chapter; and Boyce, this volume) show low GRAPE bulk densities and low acoustic impedances for this zone, which are not inconsistent with a slump interpretation. Dingle (1980) also recognized very large Neogene slumps along the outer continental margin and adjacent Cape Basin off S.W. Africa, most of which are over $100 \mathrm{~m}$ thick.

The top $60 \mathrm{~m}$ of the sediment column comprises thick to very thick-bedded $(20-150 \mathrm{~cm})$ ooze and smarl ${ }^{2}$ turbidites interbedded with pelagic calcareous oozes and marls and, in the lower $35 \mathrm{~m}$, with debrites of similar thickness to the turbidites (Fig. 12). Unlike the more muddy turbidites of the earlier brown fan sequence, these deposits show compositional gradations of foraminifers, diatoms, and nannofossils throughout. Commonly they have a coarser (silt or sand grade) parallellaminated basal portion, grading up into a thick, mas-

\footnotetext{
${ }^{2}$ Smarl = siliceous calcareous mud; see sediment classification, Introduction and Explanatory Notes, this volume.
}

sive, fine (clay grade) upper portion which is extensively burrow-mixed with the overlying ooze. There do not appear to be any very regular trends in turbidite bed thickness or grain size within this topmost unit of the brown fan.

\section{Source and Rates of Sedimentation}

In terms of sediment composition the brown fan can be divided into three units that show gradational contacts (Fig. 12). The lower one (lithologic Unit 2) is composed dominantly of terrigenous clays and calcareous nannofossils. The turbidites and debrites are muds and marls, the interbedded pelagites are foram-nannofossil oozes. The middle unit (lithologic Unit $1 \mathrm{~b}$ ), here interpreted as a major slumped sediment mass, comprises siliceous oozes, sarls, and smarls ${ }^{3}$ composed dominantly of terrigenous clays, diatoms, and nannofossils. The upper unit (lithologic Unit 1a) is similar in composition but with calcareous tests becoming more dominant than siliceous biogenic debris.

The clasts of the debrites comprise the same variety of calcareous and siliceous oozes, marls, sarls, and muds, with rare highly weathered basalt pebbles. The clay minerals throughout are composed dominantly of illite $(50-70 \%)$, with smaller $(5-20 \%)$ proportions of chlorite, kaolinite, smectite, and mixed-layer minerals.

This composition is identical to that of the sediments recovered from the top of the Walvis Ridge at the adjacent Site 532 (Site 532 summary chapter, this volume). The same threefold lithological division is also seen at Site 532 (Units 1a, 1b, and 1c), and is believed to be due to the waxing then waning influence on biological productivity and sedimentation of the Benguela upwelling system. The maximum productivity and highest rates of dominantly siliceous pelagic sedimentation were achieved in the late Pliocene-early Pleistocene (Site 532, Unit $1 \mathrm{~b})$. This coincides with the slumped sediment mass and debrites of Unit $1 \mathrm{~b}$ at Site 530 .

In light of the compositional evidence, the seismic facies geometry (Fig. 4), the thick-bedded nature of the turbidites and interbedded "coarse" (proximal) debrites, and the evidence of probable slumping, it is most likely that the redeposited sediments of the brown fan were derived locally from the Walvis Ridge. Slope instability was probably caused by a combination of seismic activity (Dingle, 1980) and slope over-steepening due to rapid sedimentation. The "rapidly" deposited pelagic siliceous oozes of the Ridge, with high water content and low shear strength, may have been particularly susceptible to failure.

Average sedimentation rates for the brown fan are just less than $3 \mathrm{~cm} / 1000 \mathrm{yr}$. for the complete sequence, about $2 \mathrm{~cm} / 1000 \mathrm{yr}$. for the lower half (late MiocenePliocene, Unit 2) and 6-7cm/ 1000 years for the upper half (Pleistocene-Holocene, Unit 1). A large proportion of the section, especially the upper part, is composed of "instantaneously"-deposited slumps, debrites, and turbidites. Leaving aside the slumps and very thick debrites, turbidity currents or debris flows have occurred relatively infrequently: on average, one every 20,000 to $25,000 \mathrm{yr}$. 


\section{DISCUSSION}

There is little doubt that at different times during the evolution of the South Atlantic, this part of the southeastern Angola Basin received large volumes of redeposited sediments. The three successions described above show some similarity to classical fan models (e.g., Walker, 1978); it remains debatable, however, just how appropriate the analogy is and to what extent the main sediment sources, rates, and controls were comparable for the different examples.

The brown fan is the only example for which there is clear bathymetric and seismic evidence of a fanshaped geometry. The estimated fan radius is about $30 \mathrm{~km}$, and Site 530 is located about $15 \mathrm{~km}$ from the probable apex at the foot of the Walvis Ridge scarp. The green fan is interpreted as a fan because of the vertical association of lobe, channel, and channel-fill sequences, but we have little clear idea about its original geometry. On the basis of the core evidence, the white fan may be more correctly interpreted as part of an irregular slope-apron sequence. However, there may have been a feeder channel from the Walvis Ridge providing a point source for the development of a fan geometry.

In all three fans, the dominant source of the turbidites or debrites was the Walvis Ridge. This is particularly clear for the mud and ooze turbidites of the brown fan, as well as for the volcanogenic sandstones of the green fan. The white fan calcarenites must have been derived from a shallow-water/exposed carbonate reef and this, I believe, indicates the existence at this time of one or more islands along the Walvis Ridge south from Site 530. The fine- and medium-grained volcanogenic sands of the green fan also must have been subjected to a period of shallow-water mechanical fragmentation and sorting prior to downslope resedimentation. The source for the brown-fan sediments has probably never been above $1000 \mathrm{~m}$ water depth.

It is interesting that, in the sequence cored at Site 530, the finest grained sediments (muds, oozes, and muddy debrites) appear to represent the most proximal part of a submarine fan. Both the volcanogenic sandstones and calcarenites show facies sequences and bed thicknesses that are from slightly more distal parts of their respective fans. Clearly, the source materials for the brown fan comprised only clay- and silt-size fractions.

There are also finer-grained, thin-bedded turbidites in the more distal parts of all three fan sequences that may have been derived from the African continental margin rather than from the Walvis Ridge. These are the quartz-rich turbidites near the base of both the green and white fans, and the then mud turbidites near the base of the brown fan.

Both the green and the brown fans (at Site 530) have accumulated about $250 \mathrm{~m}$ of sediment in 8-10 m.y. This gives an average rate of continuous sedimentation of $3 \mathrm{~cm} / 1000 \mathrm{yr}$. However, the estimated average frequency of turbidity currents supplying the green fan (1 per 2000-30,000 yr.) is an order of magnitude higher than for the brown fan ( 1 per $20,000-25,000 \mathrm{yr}$.). This difference may in part be the result of the different controls on the triggering of turbidity currents in each case. The white fan accumulated a similar thickness in 30 m.y. but with several possible hiatuses in the section. The average rate of $<1 \mathrm{~cm} / 1000 \mathrm{yr}$. is rather slow for fan sedimentation.

The three fan sequences are composed of strikingly different sediment types-volcanogenic sandstones, resedimented shallow-water carbonate debris, and deepwater biogenic muds and oozes. The primary controls on sedimentation in each case were also very different. Submarine to subaerial volcanic islands on the Walvis Ridge provided volcanic detritus for reworking in the shallow-water zone. Downslope resedimentation to the green fan was probably controlled mainly by tectonic activity on the Ridge flank related to volcanism and faulting.

The slow northward drift of the African plate into warm tropical seas led to the colonization of the volcanic highs or islands by fringing reefs or atolls. The reef talus mixed with volcanic debris provided a new source of material for growth of the white fan. The primary control on the sediment type was paleogeographical, whereas the controls on resedimentation may have been sediment-oversteepening due to upward growth of the reefs combined with storm-wave buffeting of loose reef talus and continued (probably reduced) tectonic activity.

By late Miocene, worldwide climatic cooling and a well-established deep-ocean circulation led to the development of the Benguela Current and upwelling system off S.W. Africa. Cool nutrient-rich waters reaching the surface led to greatly enhanced biological productivity and the consequent rapid accumulation of organic remains on the seafloor. This is clearly seen in the organic-carbon-rich calcareous and siliceous oozes cored at Sites 363 (Bolli, Ryan et al., 1978) and 532 (Hay, Sibuet et al., this volume) on the Walvis Ridge. These thick sediments with low density, high water content, and the potential to generate large amounts of methane and hydrogen sulfide gas were particularly unstable in Ridge flank and crestal positions. I believe that this sediment instability was the primary control on sedimentation downslope to the brown fan. Minor tectonic disturbances also may have acted as a trigger mechanism for the larger slumps and debris flows.

This sequence of volcanogenic-carbonate-pelagic turbidite sedimentation on the flanks and in the basins surrounding ocean ridges and islands has been reported from many other parts of the world's oceans (Kelts and Arthur, 1981). It is related to the growth, emergence, and subsidence of volcanic highs. It is interesting to note in this regard that the Campanian appears to have been a period of worldwide volcanism so that resedimented volcanogenic turbidites are most commonly of Campanian age.

\section{SUMMARY}

1. Three submarine fan sequences are recognized in the $1100 \mathrm{~m}$ of section recovered at Site 530: the brown 
fan (0-270 m, Miocene-Recent), the white fan (470$695 \mathrm{~m}$, Maestrichtian-Palaeogene), and the green fan (695-940 m, Santonian-Campanian).

2. The brown fan is seismically and morphologically distinct. It comprises a progradational sequence of muddy and pelagic turbidites, debrites, and slumps deposited at an average rate of $2-3 \mathrm{~cm} / 1000 \mathrm{yr}$. (1 turbidite per 25,000 yr.).

3. The white fan comprises calcilutite and calcarenite turbidites deposited more slowly $(<1 \mathrm{~cm} / 1000 \mathrm{yr}$.).

4. The green fan comprises classical thickening-upward and thinning-upward sequences of volcanogenic turbidites that reflect deposition in lobe and channel settings. The average sedimentation rate was $2-3 \mathrm{~cm} /$ $1000 \mathrm{yr}$. and the frequency of turbidites about 1 per 2000-3000 yr.

5. The primary source of sediment for all three fans was the Walvis Ridge. The primary controls on sedimentation in each case were probably different and included tectonic activity, paleogeography, oceanic circulation, and sediment type and instability.

\section{ACKNOWLEDGMENTS}

DAVS acknowledges personal support from the Natural Environment Research Council, U.K. He would also like to thank the secretarial and technical staff at the Grant Institute of Geology, and Drs. A. H. F. Robertson and K. T. Pickering for their helpful comments.

\section{REFERENCES}

Bolli, H. M., Ryan, W. B. F., et al., 1978. Init. Repts. DSDP, 40: Washington (U.S. Govt. Printing Office).

Bouma, A. H., 1962. Sedimentology of Some Flysch Deposits: Amsterdam (Elsevier).
Dingle, R. V., 1980. Large allochthonous sediment masses and their role in the construction of the continental slope and rise off southwestern Africa. Mar. Geol., 37:333-354.

Ewing, M. E., LePichon, X., and Ewing, J. I., 1966. Crustal structure of the midocean ridges: Sediment distribution in the South Atlantic Ocean and history of the Mid-Atlantic Ridge. J. Geophys. Res., 71:1611-1636.

Francheteau, J., and LePichon, X., 1972. Marginal fracture zone as structural framework of continental margins in South Atlantic Ocean. $A A P G B, 56: 991-1007$.

Goslin, J., and Sibuet, J. C., 1975. Geophysical study of the easternmost Walvis Ridge, South Atlantic: Deep structure. Geol. Soc. Am. Bull., 86:1717-1724.

Hekinian, R., 1972. Volcanics from the Walvis Ridge. Nature Phys. Sci., 239:91-93.

Kelts, K., and Arthur, M. A., 1981. Turbidites after ten years of deepsea drilling-Wringing out the map? SEPM Spec. Publ., 32: 91-127.

Moore, T. C., Rabinowitz, P. D., et al., 1981. Cruise summary: Leg 74, Walvis Ridge. Joides $J .$, 7:4-16.

Mutti, E., 1977. Distinctive thin-bedded turbidite facies and related depositional environments in the Eocene Hecho Group (Southcentral Pyrenees, Spain). Sedimentology, 24:107-131.

Mutti, E., and Ricci Lucchi, F., 1972. Le torbiditi dell' Appenino settentrionale: Introduzione all' analisi di facies. Mem. Soc. Geol. It., 11:161-199.

Stow, D. A. V., and Shanmugam, G., 1980. Sequence of structures in fine-grained turbidites: Comparison of recent deep-sea and ancient flysch sediments. Sediment. Geol., 25:23-42.

Walker, R. G., 1978. Deep water sandstone facies and ancient submarine fans: Models for exploration for stratigraphic traps. $\mathrm{Am}$. Assoc. Petrol. Geol. Bull., 62:932-966.

Walker, R. G., and Mutti, E., 1973. Turbidite facies and facies associations. In Middleton, G. V., and Bouma, A. H. (Eds.), Turbidites and Deep Water Sedimentation: Anaheim (SEPM short course), pp. 119-158.

Date of Initial Receipt: September 21, 1982 